\title{
Selective Evolution of Phenylacetamide-utilizing Strains of Pseudomonas aeruginosa
}

\author{
By JOAN L. BETZ* AND PATRICIA H. CLARKE \\ Department of Biochemistry, University College London, \\ Gower Street, London, WCI E6BT
}

(Received 5 May 1972)

\begin{abstract}
SUMMARY
Mutants of Pseudomonas aeruginosa PAC I were isolated which, unlike the wildtype, could utilize phenylacetamide as a nitrogen source for growth. One group of these mutants had lost the ability to grow on acetamide; the second group grew slowly on acetamide. Group I included I 2 mutants isolated from the magnoconstitutive butyramide-utilizing strain PAC35I and one mutant isolated from the valeramide-utilizing mutant PAC360. Group I Ph amidases hydrolysed phenylacetamide, butyramide and valeramide but not acetamide or formamide. Group II $\mathrm{Ph}$ mutants produced thermolabile amidases which attacked the same range of amide substrates but in addition had weak activity towards acetamide. Three group II mutants were derived from a constitutive butyramide-regulator mutant PACI 28; one from PAC360 and one from PAC326, a mutant producing a defective amidase.
\end{abstract}

\section{INTRODUCTION}

Pseudomonas aeruginosa wild-type amidase has a narrow range of substrates, hydrolysing aliphatic amides containing I-, 2- or 3-carbon atoms with only trace activity on the 4-carbon amide, butyramide. Acetamide and propionamide are good inducers of the enzyme and the wild-type strain is able to utilize these two amides as growth substrates. We have previously shown that mutations in either the amidase structural gene or the regulator gene, or in both genes, enable growth in a minimal salt medium with various other amides providing either the carbon or the nitrogen source for growth. Brown, Brown \& Clarke (1969) described mutants able to utilize butyramide and valeramide which produced amidases with altered substrate specificities. Brown \& Clarke (1972) isolated mutants which utilized the $\mathrm{N}$ substituted amide acetanilide ( $N$-phenylacetamide) as carbon source. The amidase produced by one of these strains differed from the wild-type enzyme by a single amino acid substitution.

As part of an investigation of directed evolution at the molecular level the substrate range of this aliphatic amidase was extended to longer chain amides and attempts were made to isolate mutants producing amidases capable of hydrolysing amides with an aromatic ring attached to the amide side chain, e.g. phenylacetamide. Various types of mutants were available as potential parental strains. Constitutive strains were thought to be advantageous since they would require only the appropriate structural gene mutation to allow hydrolysis of phenylacetamide. The most promising of these was the group of constitutive mutants of the CB series isolated by Brown \& Clarke (1970) which were resistant to repression by amide analogues. The acetanilide-utilizing mutants had been isolated from a regulator mutant

* Present address: Department of Biophysics and Genetics, University of Colorado Medical Center, Denver, Colorado, 80220, U.S.A. 
(PACI42) which was constitutive, resistant to amide analogue repression and also resistant to catabolite repression so that it produced very high enzyme levels on all media (Brown \& Clarke, 1972). This highly derepressed strain was another possible strain for the attempt to isolate phenylacetamide mutants. The other potential parental strains were the $\mathbf{B}$ and $\mathrm{v}$ series of mutants (Brown et al. 1969) which were constitutive and already possessed one or more mutations in the amidase structural gene, enabling them to hydrolyse 4- and 5-carbon amides respectively.

\section{METHODS}

Organisms. The parent strain was Pseudomonas aeruginosa PACI (8602). All strains used and isolated in this study are listed in Table $\mathrm{I}$. The symbols for genotype and phenotype are in accordance with the system proposed by Demerec, Adelburg, Clark \& Hartman (1966). The numbering of the strains in our collection is now in accordance with this system and is also compatible with systems used for other collections of Pseudomonas mutants (cf. Holloway, 1969). We have previously used series numbers for various classes of mutants and these are included for both old and new isolates to assist in identification and discussion of mutant properties.

Media. The minimal salt medium of Brammar \& Clarke (1964) was used with appropriate additions. For all solid media I \% (w/v) Oxoid no. I agar was used. The concentrations of compounds used as carbon and nitrogen source in selective plate media was as follows $(\%, \mathrm{w} / \mathrm{v}): \mathrm{S} / \mathrm{F}$, sodium succinate $(\mathrm{I} \cdot 0)+$ formamide $(0 \cdot 05) ; \mathrm{AM}$, acetamide $(0 \cdot \mathrm{I})$; B, butyramide $(\mathrm{O} \cdot \mathrm{I}) ; \mathrm{V}$, valeramide $(\mathrm{O} \cdot \mathrm{I}) ; \mathrm{H}$, hexanoamide $(\mathrm{O} \cdot \mathrm{I}) ; \mathrm{O}$, octanoamide $(\mathrm{O} \cdot \mathrm{I}) ; \mathrm{S} / \mathrm{Ph}$, sodium succinate $(\mathrm{I} \cdot 0)+$ phenylacetamide $(\mathrm{O} \cdot \mathrm{I})$. Nutrient broth was prepared from Oxoid nutrient broth no. 2 and $\mathrm{I} \cdot 2 \%(\mathrm{w} / \mathrm{v})$. Oxoid no. 3 agar was added for nutrient agar.

Plate growth tests. Strains were grown overnight in $5 \mathrm{ml}$ of nutrient broth; a loopful of culture was diluted in $2 \mathrm{ml}$ of dilution buffer and one loopful spread as a patch inoculum on the amide selective medium. Each plate was inoculated with six cultures and appropriate control cultures were included in each series of tests. The plates were incubated at $37^{\circ} \mathrm{C}$ for 3 days.

Mutagenic treatment. Methods for mutagenesis by ultraviolet (u.v.) irradiation, treatment with $N$-methyl- $N$ 'nitro- $N$-nitrosoguanidine (NMG) and ethylmethane sulphonate (EMS) were as described by Brammar, Clarke \& Skinner (1967) but for some experiments the chemical mutagens were applied to paper discs set in the centre of plates spread with the culture to be treated.

Enzyme assays. The acyl transferase assay (Brammar \& Clarke, 1964) could be used for all the amides except for formamide which reacts spontaneously with hydroxylamine at too high a rate to be used. The physiologically important reaction is amide hydrolysis and for the amides with large side-chains the insolubility in water of the corresponding acids limits the methods available. Amide hydrolysis was measured by estimating the ammonia released by the ninhydrin method as described by Brown et al. (1969). For both transferase and hydrolase activity measurements the amides were used at a concentration of $0.2 \mathrm{M}$ except for phenylacetamide which was limited by solubility to $0.05 \mathrm{M}$.

Enzyme purification. The amidases produced by the phenylacetamide-utilizing mutants were purified by methods based on those used by Brown et al. (I969) and Brown \& Clarke (I 972). The heat treatment step was omitted and $5 \%(\mathrm{v} / \mathrm{v})$ glycerol and I mM-dithiothreitol was added to the extract and to all the buffers to protect the labile amidases produced by Phv2, PhFi and Pha I (J. L. Betz, P. H. Clarke \& M. J. Smyth, in preparation).

Estimation of protein. Protein was estimated by the method of Lowry, Rosebrough, Farr \& Randall (I95I) using bovine plasma albumin as a standard. 
Starch gel electrophoresis. The methods used were those described by Brown et al. (I969). Immunodiffusion. Experiments were carried out in agar gels as described by Brown et al. (1969), but using $0.9 \mathrm{~N}-\mathrm{NaCl}$ instead of barbitone buffer to prepare the gels.

Reagents. Benzamide and phenylacetamide were obtained from British Drug Houses Ltd, Godalming, Surrey, and recrystallized twice from distilled water. Hexanoamide, octanoamide and phenylpropionamide were prepared by ammoniolysis of the acid chlorides, and mandelamide from methylmandelate by Mr P. D. Laverack. Other amides and reagents used in enzyme assays were as described by Brown et al. (I969).

\section{RESULTS}

Pseudomonas aeruginosa is unable to metabolize phenylacetate (Stanier, Palleroni \& Doudoroff, 1966) so that the media used for isolation of $\mathrm{Ph}$ mutants contained phenylacetamide as the nitrogen source and succinate or pyruvate as the carbon source. Phenylacetamide is neither a substrate nor inducer of amidase synthesis in the wild-type strain, and Brown (1969) found that it repressed amidase synthesis by the constitutive mutant PACIII. None of the mutants selected as potential strains for the isolation of phenylacetamide mutants were able to grow on succinate + phenylacetamide $(\mathrm{S} / \mathrm{Ph})$ minimal agar. Mutagenic treatments used included u.v. irradiation, and the chemical mutagens EMS and NMG. The bacteria were usually treated with the chemical mutagen, centrifuged, washed and grown in broth for several hours before plating on the selective media. For some experiments broth cultures were washed and plated on $\mathrm{S} / \mathrm{Ph}$ minimal agar and a paper disc soaked in the mutagen was placed in the centre of the plate.

Colonies of phenylacetamide-utilizing mutants appeared after 3 to 7 days of incubation at $37^{\circ} \mathrm{C}$ from some of the strains. As had been expected, none were obtained from the wildtype strain PACI. Two acetamide-negative mutants PAC307 and PAC322, both of which had the inducible wild-type regulator gene, were subjected to mutagenic treatment but no $\mathrm{Ph}$ mutants were obtained. None of the experiments with the constitutive strain PACI I I, or the constitutive mutant resistant to catabolite repression, PACI42, were successful in producing phenylacetamide mutants. Most of the mutants were obtained from strain PAC 35I. This was derived from strain PACI I I and has a further single mutation, in the structural gene, which results in the production of the mutant $\mathrm{B}$ amidase (Brown et al. 1969). Three mutants were obtained from strain PACI28. This is a constitutive strain, resistant to repression by butyramide and other amide analogues, producing the wild-type A amidase. Two mutants were obtained from strain PAC 360 , a constitutive valeramide-utilizing mutant derived from PAC 35 I by a second mutation in the amidase structural gene. Another mutant was obtained from PAC326 which is an acetamide-negative mutant derived from the constitutive, catabolite repression-resistant strain PACl42. We have previously used series numbers to identify the various groups of amidase mutants and we have continued to do this for the phenylacetamide mutants. The series number provides a convenient and simple reference to the parentage of each mutant and was useful in the preliminary grouping of the enzymes produced. Table I lists the strains used and Fig. 5 outlines the routes by which the phenylacetamide-utilizing mutants which were isolated.

\section{Growth of mutants on selective amide media}

Minimal agar plates containing amides have been used to select and identify the various mutant phenotypes. Succinate + formamide $(S / F)$ plates allow growth of constitutive strains (C series) producing $\mathrm{A}$ or $\mathrm{B}$ amidases and also a group of formamide-inducible mutants 


\section{Table I. Origin of phenylacetamide-utilizing mutants}

\begin{tabular}{|c|c|c|c|c|}
\hline Strain no.* & Series no. & Mutagen & Genotype $†$ & Phenotype + \\
\hline PACI & 8602 & & $a m i R^{+} a m i E^{+}$ & Wild type, Ind, Ami A \\
\hline $\mathrm{PAC} 307$ & Am7 & NMG & $a m i R^{+} a m i E_{7}$ & Ind, Ami-d \\
\hline PACI I I & CII & spont & $\operatorname{amiRIIamiE}{ }^{+}$ & Con, Ami A \\
\hline PACI 28 & $\mathrm{CB} 4$ & spont & $\operatorname{amiRII}, 37 a m i E^{+}$ & Con, Ami A, But-r \\
\hline PACI 42 & LIO & spont & amiR33amiE + & Con, Ami A, But-r Crp- \\
\hline PAC322 & CAM2 & NMG & $a m i R^{+} a m i E I 8$ & Ind, Ami-d \\
\hline PAC326 & LAml & NMG & $a_{m i R} 3 a_{m i E_{34}}$ & Con, Ami-d, But-r, Crp- \\
\hline $\mathrm{PAC} 35 \mathrm{I}$ & B6 & NMG & amiRIIAmiEI6 & Con, Ami B \\
\hline $\operatorname{PAC} 360$ & v9 & spont & amiRIIamiEI6,30 & Con, Ami V \\
\hline PAC 375 & PhBI & EMS & amiRIIamiEI6,65 & \multirow{18}{*}{ Con, Ami Ph } \\
\hline $\mathrm{PAC} 376$ & PhB2 & EMS & amiRIIamiEI 6,66 & \\
\hline $\mathrm{PAC} 377$ & PhB3 & EMS & amiRIIamiEI6,67 & \\
\hline $\mathrm{PAC}_{378}$ & PhB4 & EMS & amiRI I amiEI6,68 & \\
\hline $\operatorname{PAC} 379$ & PhB5 & NMG & amiRI I amiEI6,69 & \\
\hline $\mathrm{PAC}_{3} 80$ & PhB6 & EMS & amiRIIamiEI6,70 & \\
\hline $\operatorname{PAC} 382$ & Phв9 & spont & amiRIIamiEI6,72 & \\
\hline $\mathrm{PAC}_{3} 83$ & PhBi I & NMG & amiRIIamiEI6,73 & \\
\hline $\mathrm{PAC}_{384}$ & PhBI 2 & NMG & amiRIIamiEI6,74 & \\
\hline $\mathrm{PAC}_{3} 85$ & PhBI3 & spont & amiRIIamiEI6,75 & \\
\hline PAC386 & PhBI4 & NMG & amiRIIamiEI 6,76 & \\
\hline $\mathrm{PAC} 387$ & PhBi 6 & u.v. & amiRIIamiEI6,77 & \\
\hline PAC388 & Phvi & spont & amiRIIamiEI $6,30,78$ & \\
\hline $\mathrm{PAC}_{3} 89$ & Phv2 & spont & amiRI IamiEI $6,30,79$ & \\
\hline PAC39I & PhAI & EMS & $\operatorname{amiR}_{33} a \mathrm{miE}_{34,81}$ & \\
\hline $\mathrm{PAC}_{392}$ & PhF I & u.v. & $\operatorname{amiRII}, 37 \mathrm{amiE} 82$ & \\
\hline $\mathrm{PAC} 393$ & PhF2 & spont & $\operatorname{amiRII}_{3}, \mathrm{amiE}_{3}$ & \\
\hline PAC394 & PhF3 & spont & $\operatorname{amiRII,37amiE84}$ & \\
\hline
\end{tabular}

Table 2. Growth of amidase mutants on amide selective media

Plates were inoculated from overnight broth cultures diluted $10^{-2}$ and examined after 3 days of incubation at $37^{\circ} \mathrm{C}$. Each plate inoculated with six cultures to give patch growth.

\begin{tabular}{|c|c|c|c|c|c|c|c|c|}
\hline Strain no. & $\begin{array}{c}\text { Series } \\
\text { no. }\end{array}$ & $\mathrm{S} / \mathrm{F}$ & AM & B & V & $\mathrm{H}$ & $\mathrm{O}$ & $\mathrm{S} / \mathrm{Ph}$ \\
\hline PACI & WT & - & $+t$ & - & 一 & - & - & - \\
\hline PAC I I I & CI I & ++ & ++ & - & - & - & - & - \\
\hline PAC I 28 & $\mathrm{CB}_{4}$ & ++ & $+t$ & ++ & - & - & - & - \\
\hline PAC 35 I & B6 & ++ & ++ & ++ & - & - & - & - \\
\hline$P_{A C} 360$ & v9 & - & ++ & $+t$ & ++ & $\operatorname{tr}$ & - & - \\
\hline PAC 377 & PhB3 & - & - & ++ & +1 & + & + & ++ \\
\hline PAC 388 & Phvi & - & - & ++ & ++ & + & ++ & ++ \\
\hline PAC399 & Phv2 & - & $\operatorname{tr}$ & ++ & ++ & + & ++ & ++ \\
\hline PAC39I & Pha I & - & $\operatorname{tr}$ & ++ & $t+$ & + & tr & $t+$ \\
\hline $\mathrm{PAC}_{392}$ & PhF I & - & $\operatorname{tr}$ & ++ & $+t$ & $+t$ & ++ & $+t$ \\
\hline PAC393 & PhF2 & - & $\operatorname{tr}$ & ++ & ++ & $t+$ & ++ & $+t$ \\
\hline PAC394 & PhF3 & - & tr & ++ & ++ & ++ & ++ & $+t$ \\
\hline
\end{tabular}

,,$+++ \operatorname{tr}=$ Growth estimated visually; S/F, succinate $(\mathrm{I} \%, \mathrm{w} / \mathrm{v})$ and formamide $(0.05 \%) ; \mathrm{AM}$, acetamide $(0.1 \%, w / v) ; \mathrm{B}$, butyramide $(0.1 \%, \mathrm{w} / \mathrm{v}) ; \mathrm{V}$, valeramide $(0.1 \%, \mathrm{w} / \mathrm{v}) ; \mathrm{H}$, hexanoamide $(0.1 \%$, $\mathrm{w} / \mathrm{v}) ; \mathrm{O}$, octanoamide $(\mathrm{O} \cdot \mathrm{I} \%, \mathrm{w} / \mathrm{v}) ; \mathrm{S} / \mathrm{Ph}$, succinate $(\mathrm{I} \%, \mathrm{w} / \mathrm{v})+$ phenylacetamide $(0 . \mathrm{I} \%, \mathrm{w} / \mathrm{v})$. 


\title{
Table 3. Relative hydrolase activities of Pseudomonas aeruginosa mutants: washed suspensions of bacteria
}

\begin{abstract}
Samples of bacterial suspensions in tris buffer $(\mathrm{pH} 7 \cdot 2,0 \cdot 1 \mathrm{M})$ were incubated with the amidesubstrate mixtures in a total volume of $1 \mathrm{ml}$. Portions of $0.1 \mathrm{ml}$ were removed at intervals and the ammonia released measured by the ninhydrin reaction.
\end{abstract}

\begin{tabular}{|c|c|c|c|c|c|c|c|c|}
\hline \multirow{2}{*}{$\begin{array}{c}\text { Strain } \\
\text { no. }\end{array}$} & \multirow{2}{*}{$\begin{array}{c}\text { Series } \\
\text { no. }\end{array}$} & \multicolumn{6}{|c|}{ Amide substrates* } & \multirow{2}{*}{$\begin{array}{l}\mu \mathrm{mol} \text { Butyramide } \\
\text { hydrolysed } / \mathrm{min} / \mathrm{mg} \\
\text { bacteria }\end{array}$} \\
\hline & & $\mathrm{F}$ & A & $\mathbf{P}$ & B & V & $\mathrm{Ph}$ & \\
\hline PAC35I & в6 & 75 & 370 & I 200 & 100 & $\operatorname{tr}$ & 0 & $3 \cdot 0$ \\
\hline РAC 360 & v9 & ND & 45 & 200 & 100 & 8 & 0 & $8 \cdot 0$ \\
\hline PAC377 & PhB3 & 0 & 0 & 100 & 100 & 190 & 97 & 0.34 \\
\hline $\mathrm{PAC}_{3} 88$ & Phvi & $\operatorname{tr}$ & $\operatorname{tr}$ & 150 & 100 & 220 & 100 & 0.50 \\
\hline $\operatorname{PAC} 389$ & Phv2 & ND & 23 & 153 & 100 & 136 & 55 & 2.09 \\
\hline PAC 391 & PhAl & ND & 21 & 111 & 100 & I 40 & 56 & $1 \cdot 06$ \\
\hline PAC 392 & PhFI & 0 & 25 & 206 & 100 & 130 & 5.2 & $3 \cdot 0$ \\
\hline
\end{tabular}

ND, not determined; tr, trace activity.

* F, formamide; A, acetamide; P, propionamide; B, butyramide; V, valeramide; Ph, phenylacetamide.

(F series) (Brammar et al. 1967). Formamide is a poor inducer for the wild-type strain but is hydrolysed by the $\mathrm{A}$ amidase at a reasonable rate and can thus be used as a nitrogen source by the $\mathrm{C}$ and $\mathrm{F}$ strains. Mutant $\mathrm{PAC} 360$ is constitutive and produces a V-type enzyme which enables it to grow on valeramide but it cannot grow on $S / F$ plates because the $V$ amidases to not hydrolyse formamide. Brown et al. (1969) found that some of the v mutants were also unable to grow on acetamide.

The I $8 \mathrm{Ph}$ mutants were constitutive but none was able to grow on $\mathrm{S} / \mathrm{F}$ plates (Table 2). The PhB group derived from PAC35I were all acetamide-negative but some of the other mutants, Phv2, PhA I and the PhF group, produced slight growth on acetamide plates. The I 2 PhB mutants, although obtained by a variety of mutagenic treatments, were similar in growth range so that only $\mathrm{PhB}_{3}$ is listed in Table 2 . The amide growth substrates available to all the $\mathrm{Ph}$ group extended from the 4 -carbon amide butyramide and included valeramide, hexoanoamide and octanoamide as well as phenylacetamide. Compared with the very limited range of amides available for growth of the wild-type strain this group of mutants has acquired the ability to utilize a much wider range of amides. The $\mathrm{Ph}$ mutants grew well on plates containing I $\%(\mathrm{w} / \mathrm{v})$ sodium succinate with either $0 . \mathrm{I}$ or $0.2 \%(\mathrm{w} / \mathrm{v})$ phenylacetamide. With $0.3 \%(\mathrm{w} / \mathrm{v})$ phenylacetamide there was no growth even when $\left(\mathrm{NH}_{4}\right)_{2} \mathrm{SO}_{4}(0 \cdot \mathrm{I} \% \mathrm{w} / \mathrm{v})$ had been added as a nitrogen source. Growth inhibition appeared to be due to the amide itself since $0.3 \%$ phenylacetate did not affect growth. In liquid minimal salt medium with $\mathrm{I} \%(\mathrm{w} / \mathrm{v})$ sodium succinate as carbon source the mean generation time of strain PhB2 with $0.1 \%$ phenylacetamide was $\mathrm{I} 20 \mathrm{~min}$; for $0.2 \%$ phenylacetamide it was $210 \mathrm{~min}$; at concentrations of phenylacetamide $>0.25 \%$ there was no measurable growth during $20 \mathrm{~h}$.

\section{Amidase activities of bacterial suspensions}

Cultures were grown overnight in pyruvate medium, washed and resuspended in $0 \cdot 1 \mathrm{M}$-tris buffer, $\mathrm{pH} 7 \cdot 2$, at a density which would give values for the enzyme assays within the standard range. Table 3 gives the relative rates of hydrolysis of formamide, acetamide, propionamide, butyramide, valeramide and phenylacetamide with butyramide assigned an arbitrary value of 100 . Also included are values for the specific activities for butyramide as substrate. The substrate profiles of the $\mathrm{I}_{2} \mathrm{PhB}$ group of mutants (PAC375 to PAC 387 ) were 
Table 4. Relative transferase activities of Pseudomonas aeruginosa
mutants: washed suspensions of bacteria

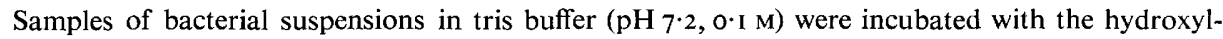
amine-amide-substrate mixture in a total volume of $\mathrm{I} \mathrm{ml}$. The reaction was stopped by the addition of $2 \mathrm{ml} . \mathrm{FeCl}_{3}$ reagent and the absorbance measured at $500 \mathrm{~nm}$.

\begin{tabular}{|c|c|c|c|c|c|c|c|}
\hline \multirow[b]{2}{*}{$\begin{array}{l}\text { Strain } \\
\text { no. }\end{array}$} & \multirow[b]{2}{*}{$\begin{array}{l}\text { Series } \\
\text { no. }\end{array}$} & \multicolumn{5}{|c|}{ *Amide substrates } & \multirow[b]{2}{*}{$\begin{array}{l}\mu \text { mol Butyrhydroxamate } \\
\text { produced } / \mathrm{min} / \mathrm{mg} \text { bacteria }\end{array}$} \\
\hline & & A & 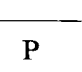 & $\hat{B}_{\mathrm{B}}$ & $\mathrm{V}$ & $\overline{\mathrm{Ph}}$ & \\
\hline PAC 35I & в6 & 800 & 300 & IOO & $\operatorname{tr}$ & 0 & $3 \cdot 0$ \\
\hline$P A C 360$ & v9 & 100 & 160 & 100 & 25 & o & $4 \cdot 0$ \\
\hline PAC 377 & Рhв3 & 0 & ND & 100 & 175 & 75 & 0.35 \\
\hline PAC 388 & Phvi & 0 & 63 & 100 & 180 & 66 & 0.46 \\
\hline PAC3 89 & Phv2 & 25 & I $80 \dagger$ & 100 & 107 & 36 & $1 \cdot 30$ \\
\hline PAC39I & Phal & 25 & $230 \dagger$ & 100 & 97 & 34 & $1 \cdot 08$ \\
\hline $\mathrm{PAC}_{392}$ & PhF I & 17 & ND & 100 & 90 & 28 & $\mathrm{I} \cdot 83$ \\
\hline
\end{tabular}

almost identical and only PAC377 has been listed; similarly the values for the three PhF group ( $\mathrm{PAC} 392$ to PAC394) were identical and only PAC392 is listed. The parent strains producing B amidase (PAC35I) and V amidase (PAC360) are shown in the same way but the constitutive mutant PACI 28 (CB4) producing wild-type A amidase is omitted. The specific activity for butyramide hydrolysis of an overnight culture of strain CB4 grown in pyruvate medium was 0.3 . The ratio for butyramide to acetamide hydrolysis rates for the wild-type A amidase is I00:5000. The A amidase has negligible activity for valeramide and no hydrolysis of phenylacetamide could be detected.

The washed suspensions of the $\mathrm{Ph}$ mutants hydrolysed all the amides tested with the exception of formamide, and in some cases acetamide. The specific activities are much lower than those of the A and B amidases for their optimal substrates. The Ph mutants thus appear to have gained an increase in the substrate range of the amidase at the expense of a decrease in the specific activity of the enzyme. For butyramide as substrate, the specific activities range from 10 to $100 \%$ of that of the $\mathrm{B}$ amidase but for valeramide, all the $\mathrm{Ph}$ mutants have specific activities which are the same or higher than most of the $v$ mutants which were isolated on valeramide. There appear to be two phenotypic groups: group I, the acetamidenegative strains, which includes the PhB mutants (PAC375 to PAC387) and PhVI (PAC388); group II, the mutants with weak acetamide activity ( $25 \%$ of the butyramide rate) which includes Phv2 (PAC398), PhaI (PAC39I) and the PhF mutants (PAC392 to PAC394). The group I mutants had lower specific activities on all the substrate amides than did the group II mutants.

The relative transferase assays for the amidases produced by the $\mathrm{Ph}$ mutants gave results which were essentially similar to those obtained for hydrolase activity (Table 4). The PhB mutants again gave identical substrate profiles as did the three PhF mutants. The group I mutants lacked acetamide transferase activity as well as hydrolase activity and the group II mutants had acetamide transferase activities of about $25 \%$ of those observed for butyramide. The results confirmed that measurements of amide transferase activity could be used to evaluate the capacity of newly isolated mutants to utilize amides for growth. 


\section{Table 5. Transferase reactions of partially purified amidases from Pseudomonas aeruginosa mutants}

Amidase activity was measured by the transferase reaction as in Table 4 . In all the preparations used the amidase comprised $60 \%$ or more of the total protein present.

Strain no. ...

Series no. ...

Amidase type ...

Amide concentration (M)

Acetamide
Propionamide
Butyramide
Isobutyramide
Valeramide
Isovaleramide
Hexanoamide
Phenylacetamide
Benzamide
Phenylpropionamide
Mandelamide

B*

$\begin{array}{ccc}\text { PAC35I } & \text { PAC377 } & \text { PAC387 } \\ \text { B6 } & \text { PhB3 } & \text { PhVI } \\ \text { B } & \text { Ph } & \text { Ph } \\ & \text { Group I } & \text { Group I }\end{array}$

0.2
0.2
0.2
0.2
0.2
0.2
0.05
0.05
0.05
0.05
0.05

690
230
100
28
$\operatorname{tr}$
$\mathrm{tr}$
$\mathrm{ND}$
0
$\mathrm{O}$
$\mathrm{ND}$
$\mathrm{O}$

0
76
100
75
123
27
186
69
0
152
11

\begin{tabular}{|c|c|c|}
\hline PAC I 28 & PAC39 I & $\mathrm{PAC}_{392}$ \\
\hline CB4 & PhAI & PhFI \\
\hline A & $\begin{array}{c}\text { Ph } \\
\text { Group II }\end{array}$ & $\begin{array}{c}\mathrm{Ph} \\
\text { Group Il }\end{array}$ \\
\hline
\end{tabular}

IOO
22
o.5
$\operatorname{tr}$
0
O
$\mathrm{ND}$
0
0
0
0

$\begin{array}{lr}\text { IOO } & 100 \\ 850 & \text { ND } \\ 385 & 277 \\ \text { ND } & 225 \\ 360 & 263 \\ \text { ND } & 23 \\ \text { ND } & 335 \\ \text { I92 } & 105 \\ \text { ND } & 5 \\ \text { ND } & 150 \\ \text { ND } & 22\end{array}$

ND, not determined; $\operatorname{tr}$, trace activity $(<5 \%)$

* Values for butyramide assigned arbitrary value of 100 .

$\uparrow$ Values for acetamide assigned arbitrary value of 100

The transferase assay was linear with the period of incubation for at least $30 \mathrm{~min}$ with all amides except propionamide for which the reaction appeared to be subject to marked substrate (or product) inhibition. This effect was more pronounced with the $\mathrm{Ph}$ group of mutants than with any of the other types of mutants, although substrate inhibition by acetamide and propionamide at high amide concentrations had been observed previously for the A and B amidases (Brown, 1969). Substrate inhibition by propionamide did not occur in the hydrolase reaction so that propionhydroxamate may have been responsible.

A concentration of $0.2 \mathrm{M}$ was used for the aliphatic amides for both hydrolase and transferase assays with all mutants. Later determinations with pure enzymes showed that this was not saturating for butyramide for the $\mathrm{PhB}$ and $\mathrm{PhVI}$ amidases but was sufficient to saturate the PhFI amidase (Table 6). If saturating concentrations of butyramide had been used it is possible that the relative specific activities for butyramide would have appeared somewhat higher. Phenylacetamide is relatively insoluble in water and the maximum concentration which could be achieved was $0.05 \mathrm{M}$ but this proved to be sufficient to saurate all the $\mathrm{Ph}$ enzymes.

\section{Amidase activities of extracts of organisms}

The results obtained with washed suspensions could have reflected differences in permeability to the various amides. Brammar, McFarlane \& Clarke (I966) had shown that the wild-type strain had a constitutive permease which enabled it to take up and concentrate acetamide and $N$-acetylacetamide. The permeability of the bacteria to other amides has not been rigorously tested, and it is not known whether the same permease is responsible for the uptake of the other amides. However, examination of the B group of mutants (Brown et al. I969) showed that the extracts had the same amide substrate profile as the intact bacteria. The $\mathrm{Ph}$ group of mutants differed considerably from the wild-type strain in substrate specificity, and the relative amide transferase and hydrolase rates of extracts of the mutants 
Table 6. Apparent kinetic constants of amidases in the transferase reaction

\begin{tabular}{ccccc} 
& \multicolumn{3}{c}{ Apparent $K_{m}(\mathrm{~mm})$} \\
Strain no. & Series no. & Acetamide & Butyramide & Phenylacetamide \\
PACI28 & CB4 & I6 & 500 & No activity \\
PAC35I & B6 & I 5 & 77 & No activity \\
PAC377 & PhB3 & No activity & I 80 & 2 \\
PAC388 & PhVI & No activity & 200 & 3 \\
PAC392 & PhFI & 120 & 38 & I
\end{tabular}

were compared with those previously obtained for whole organisms. There were no significant differences in the substrate profiles obtained, so that the relative values for extracts were similar to those given for whole organisms in Tables 3 and 4. Amides which had not been substrates of the whole organisms were not attacked by extracts. In no case was the specific activity, calculated as $\mu \mathrm{mol}$ butyramide hydrolysed $/ \mathrm{mg}$ protein $/ \mathrm{min}$, greater for extracts than for whole bacteria. In spite of the differences in the sizes of the amide molecules it did not appear that permeability was the rate determining step for amide utilization by any of the strains. These results could not completely rule out permeability limitations since breakage of the organisms could have caused some inactivation of the enzymes.

\section{Substrate range of amidases from phenylacetamide mutants}

Partially purified amidase preparations from strains PhB, PhVI, PhA I and PhFi were tested on a wider range of amides for transferase activity. Table 5 summarizes these results and compares the amidases produced by the group $\mathrm{I} \mathrm{Ph}$ mutants, which lack activity on acetamide, with the B enzyme from strain PAC35I, with the rate for butyramide set at 100 . The amidases produced by group II $\mathrm{Ph}$ mutants which have some activity towards acetamide are compared with the A amidase from strain PACI 28 with the acetamide rate set at I00. In addition to the aliphatic amides listed in Table 4 the extracts were tested on isobutyramide, isovaleramide and hexanoamide. All of these amides were substrates for the $\mathrm{Ph}$ amidases with hexanoamide being one of the best substrates. The branched chain amides were less effective as substrates than were the corresponding strain chain compounds for both the $\mathrm{Ph}$ and $\mathrm{B}$ amidases. Benzamide was not hydrolysed to a significant extent by any of the enzymes although slight activity was detected with PhFI. Mandelamide was a substrate for the three $\mathrm{Ph}$ amidases tested but the activity was very low. Phenylpropionamide was a better substrate than phenylacetamide especially for the group I enzymes.

\section{Physico-chemical properties of $P h$ amidases}

Comparison of A, B and AI amidases by starch-gel electrophoresis had shown that they differed from one another in electrophoretic mobility. The regulator phenotype of the strains producing these enzymes was such that the amidase constituted $5 \%$ or more of the total bacterial protein and appeared as the major protein band even in crude extracts. All the $\mathrm{Ph}$ mutants had been derived from parent strains with similar magno-constitutive regulatory mutations. It was possible, however, that the low specific activities of intact suspensions and crude extracts were due not only to mutations in the amidase structural gene but also to mutations in the regulator gene resulting in decreased amounts of amidase proteins. The overall protein pattern obtained with extracts of all the $\mathrm{Ph}$ mutants was similar to that of the parental type with a heavy protein band at the amidase position. However, no amidase activity could be detected at this position by the transferase reaction or hydrolase 


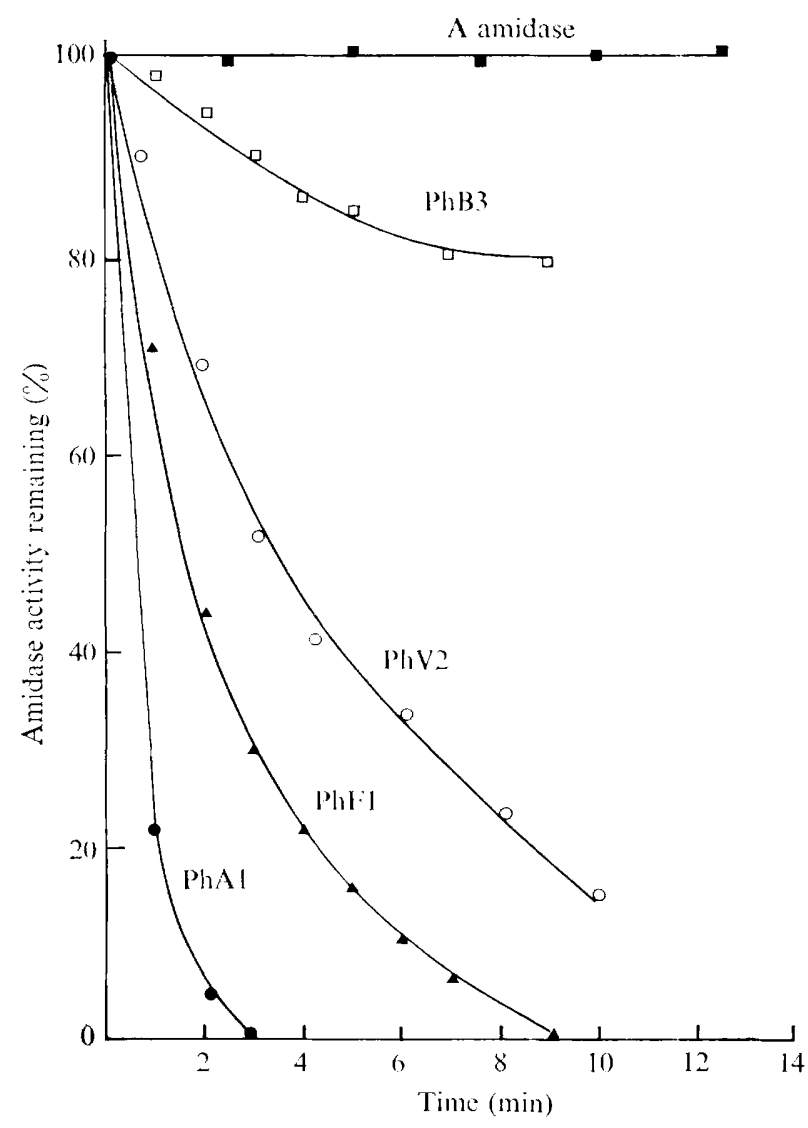

Fig. 1. Effect of heating at $60^{\circ} \mathrm{C}$ on activity of pure wild-type $\mathrm{A}$ amidase and $\mathrm{Ph}$ mutant amidases in crude extracts. - - A amidase; $\square-\square$, strain PAC377 (PhB3); $\bigcirc-O$, strain PAC389 (Phv2); - - strain Pac39r (Phal); $\Delta-\Delta$, strain PAC392 (PhFI).

reactions. It seemed likely that the heavy band was that of the amidase protein and that the lack of reaction with the amide reagents was due to the very low specific activity of the mutant enzymes and to possible inactivation during the electrophoresis.

The $\mathrm{A}$ and $\mathrm{B}$ amidases are stable to heating at $60^{\circ} \mathrm{C}$ for 10 min but the acetanilideamidase produced by mutant PAC366 (AI3) loses about $50 \%$ of its activity during this treatment (Brown \& Clarke, I972). Extracts of the Ph mutants were tested for thermal stability and gave the results shown in Fig. I. Amidases from $\mathrm{Ph}$ group I, the PhB mutants and PhvI, were relatively thermostable and retained over $80 \%$ of their activity after $10 \mathrm{~min}$. This was particularly interesting since mutant Phvi had been obtained by an additional mutation in the structural gene of strain PAC360 (v9) which has an unstable amidase. Mutants of $\mathrm{Ph}$ group II produced thermolabile amidases. The half-life of the enzymes at $60{ }^{\circ} \mathrm{C}$ was $0.5 \mathrm{~min}$ for PhAI and 2.5 to 3 min for the enzymes from PhFI and Phv2. This thermal lability of the enzymes was confirmed with a purified preparation of the PhFI amidase.

The amidases produced by the $\mathrm{Ph}$ group II mutants were also unstable at low temperatures. Extracts stored at $4{ }^{\circ} \mathrm{C}$ lost all activity in a few days but the addition of $5 \%(\mathrm{v} / \mathrm{v})$ glycerol together with dithiothreitol (I $\mathrm{mM}$ ) to the crude extract more than tripled the half-life of the enzymes. Extracts containing A, B or Ph group I amidases (PhB and Phvi) could be stored 


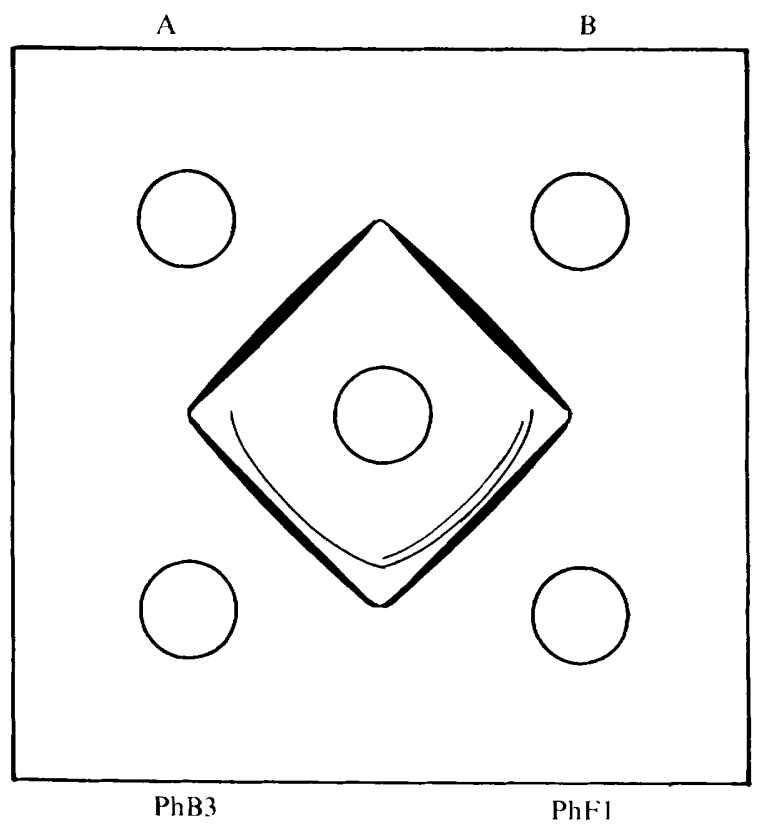

Fig. 2. Immunodiffusion reactions in agar gels. The centre well contains antiserum to purified A amidase. The outside wells contain pure preparations of $\mathrm{A}$ and $\mathrm{B}$ amidases and crude extracts of PhB3 and PhFI.

at $4{ }^{\circ} \mathrm{C}$ for several months with very little loss of activity. Group II $\mathrm{Ph}$ amidases lost activity very rapidly if frozen and thawed, whereas the $\mathrm{A}, \mathrm{B}$ and $\mathrm{PhB}$ amidases retained almost all their original activity after this treatment.

Extracts and partially purified preparations were tested for immunodiffusion crossreactions with antisera prepared against $\mathrm{A}$ and $\mathrm{B}$ amidases. All the $\mathrm{Ph}$ amidases gave complete cross-reactions but in addition to the major band which indicated complete antigenic homology with A and B amidases there were fainter precipitin lines which appeared to the inside of the major band as shown in Fig. 2. Extracts which had been stored for some time and had lost amidase activity gave only the inner precipitin lines which might represent a dissociated form of the enzyme.

\section{Comparison of kinetic constants}

Apparent Michaelis constants were determined with amidase preparations containing at least $60 \%$ pure enzyme from the phenylacetamide mutants PhB3, Phvi, PhFi (PAC377, PAC388 and PAC392) and $\mathrm{B} 6$ (PAC35I). Fig. 3 gives the Lineweaver-Burk plots for PhFI, PhvI and B6 with butyramide and Fig. 4 for PhFI, Phvi and PhB3 with phenylacetamide. The specific activities of these enzymes have not been accurately determined since they tend to lose activity on storage. It was therefore not possible to make valid calculations for $V_{\max }$ from these data. However, comparison of the specific activities of the enzymes during purification confirmed the observations made with whole organisms and extracts that the amidases produced by the phenylacetamide mutants are much less active on their best substrates, e.g. valeramide, than are the $\mathrm{A}$ and $\mathrm{B}$ enzymes on their best substrates, e.g. acetamide and propionamide. The apparent $K_{m}$ values for the enzymes produced by PhB3 and Phvi are higher for butyramide than that previously measured for the B amidase but the enzyme 


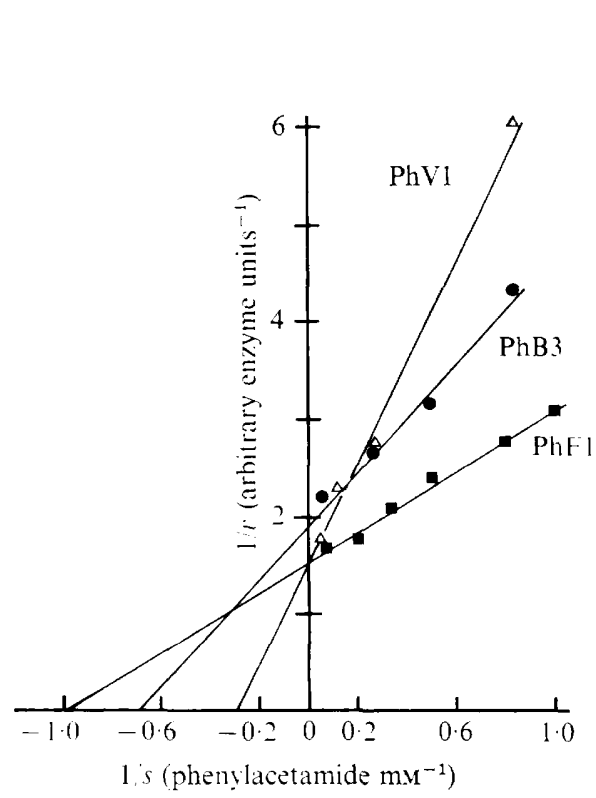

Fig. 3

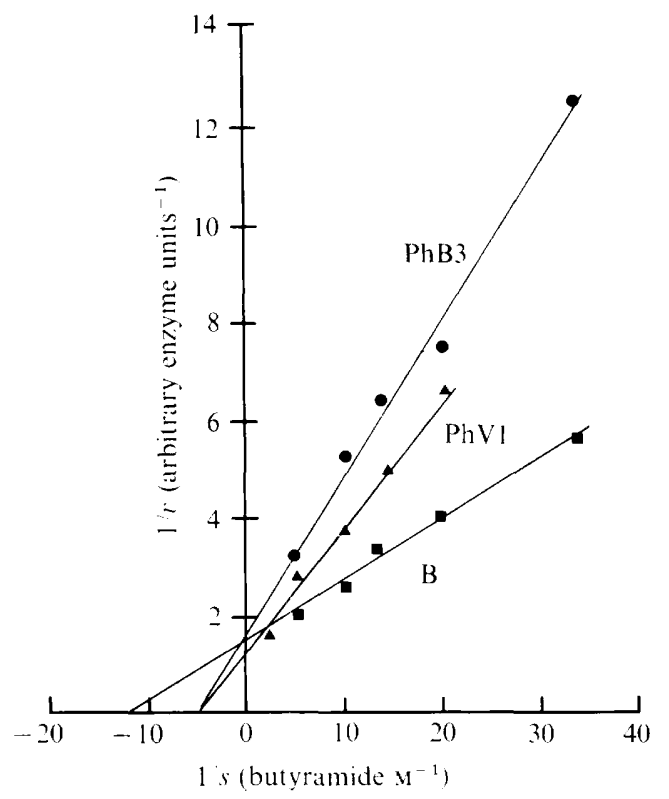

Fig. 4

Fig. 3. Lineweaver-Burk plot for determination of apparent $K_{m}$ for butyramide of amidase produced by strain PAC392 (PhFI), PAC388 (PhVI) and PAC35I (B6).

Fig. 4. Lineweaver-Burk plot for determination of apparent $K_{m}$ for phenylacetamide of amidase produced by strain PAC392 (PhF1), PAC388 (PhVI) and PAC377 (PhB3).

produced by mutant PhFi has a significantly lower $K_{m}$ value. For phenylacetamide as substrate all three mutant enzymes have low $K_{m}$ values of I to $3 \mathrm{mM}$. Only the PhFI amidase was able to attack acetamide and the $K_{m}$ for this amide was tenfold greater than the values determined for the A and B amidases (Brown et al. 1969).

\section{DISCUSSION}

Phenylacetamide-utilizing strains of Pseudomonas aeruginosa were evolved from the acetamide-utilizing wild-type and there was not a unique mutational pathway for the successive changes in the genes concerned. Fig. 5 outlines the steps by which the five individually distinct phenylacetamide mutants were obtained; all the others isolated belonged to one or another of these classes. All the Ph mutants are constitutive and have a mutation in the amidase regulator gene, amiR. Only PAC392 ( $\mathrm{PhFI})$ was derived by a single mutation in the structural gene and is therefore likely to differ from the wild-type by a single amino acid change. PAC377 (PhB3) and PAC39I (PhA1) must have have two mutations, although these could have been in the same codon on each occasion and do not necessarily involve changes in two amino acids. The Phv mutants, PAC388 and PAC389, must have had three mutational changes but again this need not mean changes in three separate amino acids in the protein chain. It was particularly interesting that two different amidases were obtained by spontaneous mutation of the amidase structural gene of strain PAC360 (v9). The Phvi and Phv2 proteins differed both in substrate profile and thermal stability and must therefore have had quite different amino acid substitutions.

Whereas the amidase produced by the parent strain PAC360 (v9) was very unstable in 


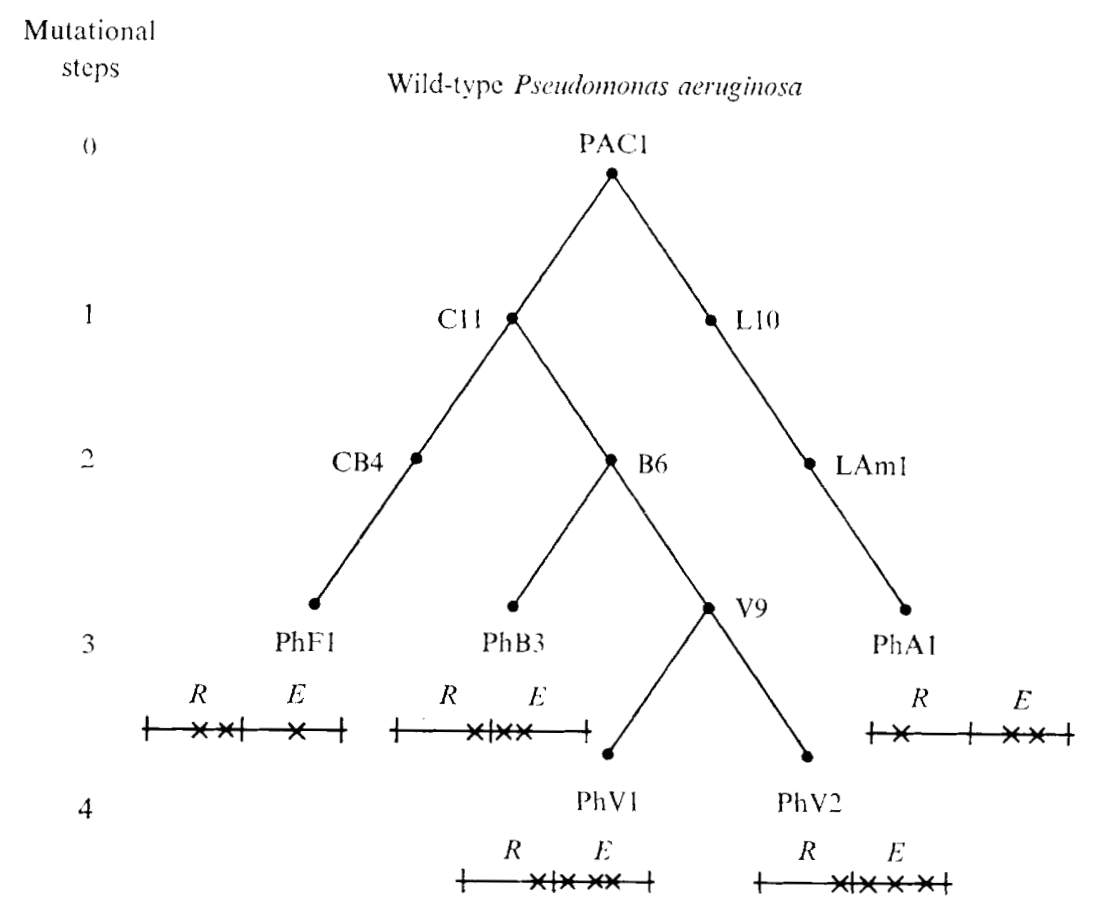

Fig. 5. Derivation of phenylacetamide-utilizing strains. Genotype abbreviations: amiR, amidase regulator gene; amiE, amidase structural gene. Genotypes of amidase mutants: CI I, amiRI IamiE ; CB4, amiRII,37amiE ; PhFI, amiRII,37amiE82; B6, amiRIIamiEI6; PhB3, amiRIIamiEI6,67; v9, amiRiamiEı6,30; Phvi, amiRIramiEI6,36,78; Phv2, amiRIIamiEI6,30,79; Lio, amiR33amiE ${ }^{+}$; LAml, amiR33amiE34,8I; PhAI, amiE33amiE34,8I. See also Table I.

extracts, the enzymes produced by both Phvi and Phv2 were stable enough for their properties to be investigated, although the Phv2 amidase was thermolabile. In a certain sense the additional mutations in the two strains derived from v9 could be considered to be internal suppressor mutations allowing the production of more stable enzymes. As far as activity with valeramide as a substrate is concerned, both the mutations have resulted in amidases with higher specific activities for valeramide hydrolysis. We observed previously that some of the mutants isolated on valeramide plates, after mutagenesis of the butyramideutilizing strain PAC35I, had higher specific activities for butyramide hydrolysis than the parent strain which had been isolated on butyramide medium. This suggested that if mutant strains were required to attack a specific amide it might be advantageous to select for them on a medium containing an amide with a larger side-chain than the required substrate. We have confirmed this finding with the present series of mutants. Valeramide and hexoanoamide are the optimum substrates for all the phenylacetamide group of mutants.

The mutants we have described represent five possible lines of evolution of phenylacetamide-utilizing strains. However, these strains are all constitutive and in nature such enzymes are usually inducible. It is possible that a further mutation in the amidase regulator gene could lead to an inducible phenylacetamide-utilizing strain. We have previously shown that the regulator gene product may respond in different ways to amide inducers and inducer analogues. The wild-type strain, and such constitutive mutants as PACIII, are subject to amide analogue repression by butyramide, while other constitutive mutants like PACI 28 are 
resistant and grow on butyramide. A mutation in the regulator gene which led to butyramideinducibility would also allow growth on butyramide but this type of mutation has not been encountered among the Pseudomonas aeruginosa mutants which have been isolated so far. However, P. putida and P. acidovorans grown on acetamide and butyramide and the enzyme is induced by both amides (Clarke, 1972). Mutations leading to alterations in inducer specificity can occur in P. aeruginosa, and Brammar et al. (1967) isolated mutants with an increased rate of induction by formamide, which grew on succinate + formamide medium.

This series of phenylacetamide mutants does not necessarily represent the end of possible evolution of a phenylacetamide-utilizing phenotype. It might be an advantage for a strain to acquire further regulator mutations to enable phenylacetamide to act as an inducer, and it might also be a selective advantage to introduce further mutations in the structural gene which would increase the specific activity of the amidases, and, in the case of group II mutants, to increase the enzyme stability. Although all five of the different phenylacetamide mutants grew equally well under the laboratory conditions under which they were tested, it may well be that under the more competitive situation of utilizing phenylacetamide in the natural environment some differences would be apparent. If any one of the mutants could outgrow the others it might then undergo some further mutations and eventually reach a stable genotype and fill an ecological niche not available to the original wild-type strain.

Stephenson (1949) commented that bacterial evolution was still continuing and suggested that biochemical evolution in bacteria could be controlled and imitated in the laboratory. Attempts have been made by several workers to analyse the mutational changes occurring during the acquisition of new metabolic pathways. Hegeman \& Rosenberg (1970) pointed out that this is frequently achieved by a regulatory mutation. If a compound is a substrate for an enzyme already present in the organism, but not an inducer of the enzyme, then a mutation to constitutivity may allow growth to occur. This type of mutation in Pseudomonas aeruginosa produced the regulatory mutants of the CB series which were able to grow on butyramide. Mortlock, Fossitt \& Wood (1965) had previously shown that mutations in Aerobacter aerogenes which allowed growth on certain alcohols and sugars, not utilized by the parent strains, involved constitutive enzyme synthesis. In some cases constitutive synthesis of specific permeases may also enable growth to occur on new substrates. Wu, Lin \& Tanaka (1967) described a series of mutations in A. aerogenes which produced mutants able to grow on xylitol. This is a substrate for ribitol dehydrogenase, but not an inducer, and the first mutation resulted in constitutive synthesis of ribitol dehydrogenase. A second mutation resulted in a ribitol dehydrogenase with a higher affinity for xylitol and this mutant therefore carried both a regulator and structural gene mutation and was analogous to the constitutive $P$. aeruginosa mutants producing altered enzymes. A third mutation in A. aerogenes resulted in the constitutive synthesis of an arabitol permease which is also able to transport xylitol into the cell and this mutant was able to grow on xylitol at a faster rate than the two earlier mutants.

If strains of bacteria are required to carry out particular metabolic reactions it may be possible to improve on the naturally occurring species by selecting for regulatory mutations allowing constitutive synthesis of enzymes (or permeases) which already possess weak affinities for the required substrates. Successive selection under conditions where these substrates are essential for growth might then allow the selection of new strains producing mutant enzymes and then strains which could be induced by the new growth substrates. The metabolic pathways for the degradation of biological compounds have evolved over millenia but it is possible that new pathways for the degradation of unwanted and persistent chemicals could arise by the application of these principles of directed evolution. 


\section{REFERENCES}

Brammar, W. J. \& Clarke, P. H. (1964). Induction and repression of Pseudomonas aeruginosa amidase. Journal of General Microbiology 37, 307-319.

Brammar, W. J., Clarke, P. H. \& Skinner, A. J. (i967). Biochemical and genetic studies with regulator mutants of the Pseudomonas aeruginosa 8602 amidase system. Journal of General Microbiology 47, 87-102.

Brammar, W. J., McFarlane, N. D. \& Clarke, P. H. (I966). The uptake of aliphatic amides by Pseudomonas aeruginosa. Journal of General Microbiology 44, 303-309.

Brown, J. E. (1969). Regulator and structural gene mutants of Pseudomonas aeruginosa amidase. Ph.D. Thesis, University of London.

Brown, J. E., Brown, P. R. \& Clarke, P. H. (I969). Butyramide-utilizing mutants of Pseudomonas aeruginosa 8602 which produce an amidase with altered substrate specificity. Journal of General Microbiology 57, 273-295.

Brown, J. E. \& ClaRKe, P. H. (1970). Mutations in a regulator gene allowing Pseudomonas aeruginosa 8602 to grow on butyramide. Journal of General Microbiology 64, 329-342.

Brown, P. R. \& ClaRKE, P. H. (1972). Amino acid substitution in an amidase produced by an acetanilideutilizing mutant of Pseudomonas aeruginosa. Journal of General Microbiology 70, 287-298.

Clarke, P. H. (1972). Biochemical and immunological comparison of aliphatic amidases produced by Pseudomonas species. Journal of General Microbiology 71, 24I-257.

Demerec, M., Adelburg, E. A., Clark, A. J. \& Hartman, P. E. (1966). A proposal for a uniform nomenclature in bacterial genetics. Genetics $54,6 \mathrm{I}-76$.

Hegeman, G. D. \& Rosenberg, S. L. (1970). The evolution of bacterial enzyme systems. Annual Review of Microbiology 24, 429-462.

Holloway, B. W. (1969). Genetics of Pseudomonas. Bacteriological Reviews 33, 4I9-443.

Lowry, O. H., Rosebrough, N. J., FARr, A. L. \& Randall, R. J. (I95I). Protein measurement with the Folin phenol reagent. Journal of Biological Chemistry 193, 265-275.

Mortlock, R. P., Fossitr, D. D. \& Wood, W. A. (1965). A basis for utilization of unnatural pentoses and pentitols by Aerobacter aerogenes. Proceedings National Academy of Sciences of the United States of America 54, 572-579.

Stanier, R. Y., Palleroni, N. J. \& Doudoroff, M. (1966). The aerobic pseudomonads; a taxonomic study. Journal of General Microbiology 43, I 59-27I.

Stephenson, M. (1949). Bacterial Metabolism, 3rd edn, p. 31 I. London: Longmans, Green \& Co.

Wu, T., LIN, E. C. \& TANAKA, S. (1968). Mutants of Aerobacter aerogenes capable of utilizing xylitol as a novel carbon source. Journal of Bacteriology 96, 447-456. 